\title{
P-limitation of respiration in the Sargasso Sea and uncoupling of bacteria from P-regeneration in size-fractionation experiments
}

\author{
Ingrid Obernosterer ${ }^{1,2}$, Nobu Kawasaki ${ }^{1}$, Ronald Benner ${ }^{1, *}$ \\ ${ }^{1}$ University of South Carolina, Department of Biological Sciences and Marine Science Program, Columbia, \\ 29208 South Carolina, USA \\ ${ }^{2}$ Present address: Observatoire Océanologique, CNRS UMR 7621, BP 44, 66651 Banyuls sur Mer, France
}

\begin{abstract}
Community respiration rates were measured in unfiltered seawater collected in the upper $75 \mathrm{~m}$ of the water column along a transect in the Sargasso Sea and at the Bermuda Atlantic Time-series Study (BATS) station (31 $50^{\prime} 00 \mathrm{~N}_{i} 64^{\circ} 10^{\prime} 00 \mathrm{~W}$ ) during a cruise in June and July 2001. Community respiration rates in the upper $75 \mathrm{~m}$ of the water column averaged $1.1 \pm 0.4 \mu \mathrm{M} \mathrm{O}_{2} \mathrm{~d}^{-1}$ and exhibited significant spatial and temporal variability. Concurrent determination of the heterotrophic and autotrophic community revealed no relationship between community respiration and the abundance of any of the major metabolic groups. Addition of inorganic nutrients $\left(\mathrm{NO}_{3}\right.$ and $\left.\mathrm{PO}_{4}\right)$ and organic carbon (glucose) indicated that community respiration was P-limited in the surface mixed layer. Size-fractionation experiments indicated that the abundance of heterotrophic bacteria in the $<0.6 \mu \mathrm{m}$ fraction was $\sim 80 \%$ of the abundance in unfiltered seawater, but respiration rates in the $<0.6 \mu \mathrm{m}$ size fraction accounted for only $23 \%$ of community respiration. Addition of $\mathrm{P}$ to the $<0.6 \mu \mathrm{m}$ size fraction increased respiration rates $\sim 2$-fold, indicating bacterial respiration was P-limited. It appears that the uncoupling of bacteria from nutrient regeneration in size fractionation experiments resulted in a reduction of bacterial metabolism in the P-limited surface waters of the Sargasso Sea.
\end{abstract}

KEY WORDS: Community respiration $\cdot$ Size-fractionation $\cdot$ P-limitation $\cdot$ Sargasso Sea $\cdot$ BATS

\section{INTRODUCTION}

About half the marine primary production passes through the reservoir of dissolved organic carbon (DOC) and is processed by heterotrophic bacterioplankton (Cole et al. 1988, Ducklow 2000). A strong spatial and temporal coupling between these processes has been suggested by concurrent measurements of phytoplankton and bacterial production and biomass (Kirchman et al. 1991, White et al. 1991). However, there is increasing evidence suggesting that DOC may accumulate in the photic zone on both daily and seasonal timescales (Copin-Montégut \& Avril 1993, Carlson et al. 1994, Zweifel et al. 1995). This indicates that the processing of DOC by heterotrophic bacterioplankton might be temporally lim- ited by the availability of nitrogen or phosphorus (Williams 1995).

To determine the factors limiting the processing of DOC, most previous studies have investigated heterotrophic bacterial production (Zweifel et al. 1993, Kirchman \& Rich 1997, Rivkin \& Anderson 1997), while a limited number of studies have addressed the factors limiting heterotrophic bacterial respiration (Pomeroy et al. 1995, Smith \& Kemp 2003). A large fraction of community respiration is attributable to the oxidation of DOC, making respiration measurements a relatively straightforward and quantitative estimate of the biological processing of organic carbon (Williams 1984, Hopkinson et al. 1989).

Limitation of heterotrophic bacterial production by inorganic nutrients has been reported for both fresh- 
water (Currie \& Kalff 1984, Vadstein et al. 1988, Toolan et al. 1991) and marine systems. Several studies performed in the Atlantic Ocean (Cotner et al. 1997, Rivkin \& Anderson 1997, Kuipers et al. 2000) and in marginal seas (Pomeroy et al. 1995, Thingstad \& Rassoulzadegan 1995, Zweifel et al. 1995) indicate that $P$ is often the primary limiting nutrient for marine heterotrophic bacterial production. In contrast, heterotrophic bacterial production in the Pacific Ocean has been characterized by several authors as organic carbon- or energy-limited (Kirchman 1990, Cherrier et al. 1996, Kirchman \& Rich 1997, Donachie et al. 2001). These studies show that the factors limiting heterotrophic bacterial production vary spatially and temporally. They further indicate that the degree to which bacterial metabolism is limited by sources other than carbon often influences the coupling between primary production and the processing of DOC.

The bacterial contribution to community respiration is commonly assessed by size fractionation (Williams 1981, Griffith et al. 1990, Danieri et al. 1994, Sampou \& Kemp 1994). However, separation of the microbial community by size fractionation bears a major disadvantage. Interactions among microbial communities of different size classes are inhibited by size fractionation, which in turn can affect their overall metabolic activity (Sherr et al. 1988). The interaction of members of different metabolic groups and size classes might be particularly important in oligotrophic environments that are characterized by low concentrations of substrates and rapid cycling of inorganic nutrients (Legendre \& Rassoulzadegan 1995).

In the present study we report that community and bacterial respiration is P-limited during the summer in surface waters of the Sargasso Sea, and our results further indicate that bacterial respiration could be underestimated in size-fractionation experiments due to the separation of various functional groups of the microbial community.

\section{MATERIALS AND METHODS}

The present study was carried out during a cruise aboard RV 'Cape Hatteras' along a transect in the Sargasso Sea and at the Bermuda Atlantic Time-series Study (BATS) site between 20 June and 11 July 2001 (Table 1). Seawater samples were collected using $30 \mathrm{l}$ Niskin bottles mounted on a General Oceanics rosette sampler equipped with a CTD (Seabird 911).

Respiration rate measurements. Community respiration rates were measured in dark incubations of unfiltered seawater in 300 and $60 \mathrm{ml}$ BOD bottles. Seawater was collected from the upper $25 \mathrm{~m}$ at all stations and from the surface to $75 \mathrm{~m}$ depth at BATS and Stns 4 and 5 (Table 1). The depth of the surface mixed layer varied from 6 to $26 \mathrm{~m}$. The depth of the surface mixed layer was determined based on the temperature profile. Seawater was collected within the surface mixed layer in 10 out of 14 experiments. Except for Stns 1 and 3 , water samples were collected between 07:00 and 10:00 $\mathrm{h}$ throughout the cruise, and on 2 consecutive days water samples were additionally collected at 16:30 and 20:00 h.

The BOD bottles were filled directly from Niskin bottles with unfiltered seawater using silicon tubing. Prior to sampling, the BOD bottles were rinsed with $1 \mathrm{~N}$ HCL, Milli-Q water and seawater ( $3 \times$ ) from the respective depth layer. Continuous water flow from the Niskin bottle was allowed throughout the sampling procedure. Respiration measurements were performed in triplicate or quadruplicate in the dark at in situ temperatures $\left( \pm 1^{\circ} \mathrm{C}\right)$. Except for 3 time-course experiments (see below) all BOD bottles were incubated for $24 \mathrm{~h}$. The respiration rate was calculated as the difference between initial and final concentrations of dissolved oxygen. The concentration of dissolved oxygen was determined by Winkler titration of a $50 \mathrm{ml}$ subsample with an automated potentiometric end-point detection system (Biddanda et al. 1994). No statistical difference in respiration rates between 60 and $300 \mathrm{ml}$ BOD bottles was observed ( $t$-test, $\mathrm{p}>0.05$ ).

To evaluate the kinetics of respiration during a $48 \mathrm{~h}$ incubation period, time-course experiments were performed at Stns 1 and 3 and at BATS (Table 1). Unfiltered seawater collected at $25 \mathrm{~m}$ depth at Stns 1 and 3 and at $22 \mathrm{~m}$ depth at BATS was incubated in BOD bottles as described above. The decrease in dissolved oxygen concentration was determined at Stns 1 and 3 after 24 and $48 \mathrm{~h}$ and at BATS after 12, 24, 36 and $48 \mathrm{~h}$, each sample in triplicate BOD bottles. Respiration rates were determined as the slope of a linear regression of the time-course data.

Size fractionation. The contribution of bacterioplankton to community respiration was determined in water samples that were passed through $0.6 \mu \mathrm{m}$ poresize Nuclepore QR polycarbonate filter cartridges

Table 1. Location of sampling stations in the Sargasso Sea. BATS: Bermuda Atlantic Time-series Study

\begin{tabular}{|lccc|}
\hline Station & Date $(\mathrm{mm} / \mathrm{dd})$ & Lat $\left({ }^{\circ} \mathrm{N}\right)$ & Long $\left({ }^{\circ} \mathrm{W}\right)$ \\
\hline 1 & $06 / 21$ & $34^{\circ} 26^{\prime} 30$ & $72^{\circ} 34^{\prime} 19$ \\
2 & $06 / 22$ & $36^{\circ} 10^{\prime} 25$ & $70^{\circ} 43^{\prime} 07$ \\
3 & $06 / 23$ & $36^{\circ} 46^{\prime} 76$ & $69^{\circ} 09^{\prime} 00$ \\
BATS & $06 / 27-07 / 07$ & $31^{\circ} 50^{\prime} 00$ & $64^{\circ} 10^{\prime} 00$ \\
4 & $07 / 08$ & $31^{\circ} 50^{\prime} 07$ & $66^{\circ} 14^{\prime} 73$ \\
5 & $07 / 09$ & $32^{\circ} 16^{\prime} 71$ & $69^{\circ} 00^{\prime} 99$ \\
\hline
\end{tabular}


using a peristaltic pump. The $<0.6 \mu \mathrm{m}$ filtrate was incubated in $60 \mathrm{ml}$ BOD bottles for $24 \mathrm{~h}$ as described above.

Long-term experiments. In addition to $24 \mathrm{~h}$ incubations, respiration rates were also measured during long-term experiments performed at BATS. Seawater was collected from 50,150 and $300 \mathrm{~m}$ and filtered through $0.6 \mu \mathrm{m}$ pore-size Nuclepore QR polycarbonate filter cartridges and incubated in $60 \mathrm{ml}$ BOD bottles at $20 \pm 1^{\circ} \mathrm{C}$ for 5 to $10 \mathrm{~d}$.

Nutrient enrichment experiments. The effect of organic carbon (glucose) and inorganic $\left(\mathrm{NO}_{3}\right.$ and $\left.\mathrm{PO}_{4}\right)$ nutrient additions on respiration rates was determined during short- (24 h) and long-term (5 d) experiments at BATS and at Stn 5. Unfiltered seawater samples (24 h incubations) were transferred to BOD bottles as described above and subsequently spiked with nutrients resulting in final concentrations of $1 \mu \mathrm{M}$ glucose and $\mathrm{NO}_{3}$ and $0.1 \mu \mathrm{MPO}_{4}$. Either single nutrients or a combination of all nutrients were added to seawater collected in the surface mixed layer, at 30, 40, 50 and $75 \mathrm{~m}$. Additionally, at BATS, $\mathrm{PO}_{4}$-amended $(0.1 \mu \mathrm{M}$ final conc.) $0.6 \mu \mathrm{m}$ filtered seawater collected at 10 and $50 \mathrm{~m}$ was incubated for 1 and $5 \mathrm{~d}$, respectively. All nutrient stocks were prepared in deionized Milli-Q water and kept frozen until used. Incubation of the nutrient-amended treatments followed the protocol described above.

Enumeration of the heterotrophic and autotrophic community. For enumeration of the plankton community in unfiltered seawater and the $<0.6 \mu \mathrm{m}$ size fraction, duplicate $15 \mathrm{ml}$ subsamples were fixed with $2 \%$ formaldehyde (final conc.) and stored at $4{ }^{\circ} \mathrm{C}$ for $\sim 3 \mathrm{wk}$. In the laboratory, $10 \mathrm{ml}$ subsamples were stained with DAPI (Porter \& Feig 1980) and filtered onto black Nuclepore filters $(0.2 \mu \mathrm{m}$ pore size). Subsequent enumeration was performed with an epifluorescence microscope (Olympus BX) at $1250 \times$ magnification. The abundance of heterotrophic bacteria and heterotrophic protists was determined using an excitation filter of $365 \mathrm{~nm}$, while an excitation wavelength of $480 \mathrm{~nm}$ was used for the enumeration of autofluorescent cells (Sherr et al. 1993). For bacterial abundance at least 300 bacteria per sample were counted and 60 fields were enumerated for the abundance of heterotrophic protists, cyanobacteria and autotrophic nanoplankton.

\section{RESULTS}

\section{Community respiration rates}

Time-course experiments with unfiltered seawater revealed a fairly linear decrease in the concentration of dissolved oxygen over a $48 \mathrm{~h}$ incubation period at Stns 1 and 3 and at BATS (Fig. 1). The average respira-
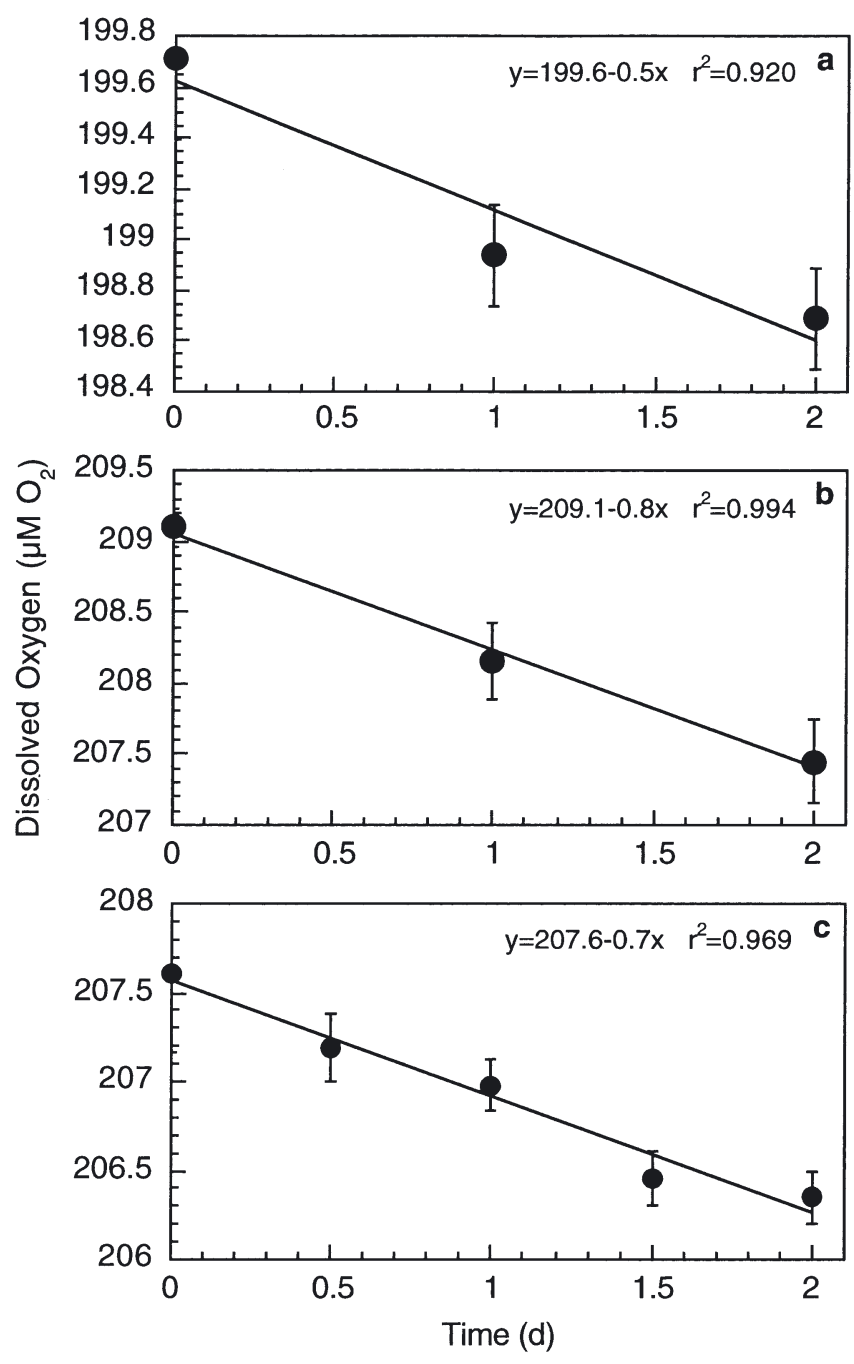

Fig. 1. Changes in dissolved oxygen concentration over time in unfiltered seawater collected at (a) $25 \mathrm{~m}$ at Stn 1, (b) $25 \mathrm{~m}$ at Stn 3 , and (c) $22 \mathrm{~m}$ at the Bermuda Atlantic Time-series Study (BATS) station. Error bars represent the SD of 3 replicate bottles

tion rate derived from the 3 time-course experiments was $0.7 \pm 0.2 \mu \mathrm{MO}_{2} \mathrm{~d}^{-1}$. Based on these results, it appears respiration rates were linear during the $24 \mathrm{~h}$ incubations used in this study.

Community respiration rates averaged $1.3 \pm$ $0.5 \mu \mathrm{MO}_{2} \mathrm{~d}^{-1}(\mathrm{n}=8)$ in the surface mixed layer and $1.1 \pm 0.4 \mu \mathrm{MO}_{2} \mathrm{~d}^{-1}(\mathrm{n}=20)$ in the upper $75 \mathrm{~m}$ of the photic zone of the Sargasso Sea (Table 2). The average respiration rate in the upper $75 \mathrm{~m}$ at BATS $(1.1 \pm$ $0.4 \mu \mathrm{MO}_{2} \mathrm{~d}^{-1}, \mathrm{n}=10$ ) was similar to that determined for the other stations sampled in the Sargasso Sea $\left(1.0 \pm 0.4 \mu \mathrm{MO}_{2} \mathrm{~d}^{-1}, \mathrm{n}=10\right.$; Table 2). In the present study, respiration rates $\leq 0.2 \mu \mathrm{MO}_{2} \mathrm{~d}^{-1}$ were not significantly different from zero (Table $2 ; t$-test, $\mathrm{p}>0.05$ ). Respiration rates $\leq 0.2 \mu \mathrm{MO}_{2} \mathrm{~d}^{-1}$ are not included in the average rates given above. 


\section{Abundance of the major groups of the heterotrophic and autotrophic community}

Bacterial abundance in unfiltered seawater from the surface mixed layer of the Sargasso Sea was $2.3 \pm$ $0.5 \times 10^{8}$ cells l$^{-1}(\mathrm{n}=10)$. A similar average bacterial

Table 2. Community respiration rates in the Sargasso Sea in June and July 2001. Respiration rates \pm pooled SD of initial and final dissolved oxygen concentration are given; $\mathrm{n}=3$ or $\mathrm{n}=4$. SML: surface mixed layer; BATS: Bermuda Atlantic Time-series Study

\begin{tabular}{|c|c|c|c|c|c|}
\hline $\begin{array}{l}\text { Study } \\
\text { station }\end{array}$ & $\begin{array}{c}\text { Date } \\
(\mathrm{mm} / \mathrm{dd})\end{array}$ & $\begin{array}{c}\text { Time } \\
\text { of } \\
\text { sampling }\end{array}$ & $\begin{array}{l}\text { Sampling } \\
\text { depth } \\
\text { (m) }\end{array}$ & $\begin{array}{l}\text { Depth } \\
\text { of SML } \\
\text { (m) }\end{array}$ & $\begin{array}{c}\text { Respiration } \\
\text { rate } \\
\left(\mu \mathrm{M} \mathrm{O}_{2} \mathrm{~d}^{-1}\right)\end{array}$ \\
\hline 1 & $06 / 21$ & $12: 30 \mathrm{~h}$ & 25 & 11 & $0.8 \pm 0.3$ \\
\hline 2 & $06 / 22$ & 09:00 h & 25 & 26 & $0.5 \pm 0.2$ \\
\hline 3 & $06 / 23$ & $14: 30 \mathrm{~h}$ & 25 & 15 & $1.0 \pm 0.2$ \\
\hline \multirow{11}{*}{ BATS } & $06 / 27$ & 07:00 h & 2.5 & 10 & $1.5 \pm 0.6$ \\
\hline & $06 / 28$ & 07:00 h & 5 & 10 & $1.4 \pm 0.3$ \\
\hline & $06 / 28$ & $16: 30 \mathrm{~h}$ & 2 & 6 & $1.2 \pm 0.2$ \\
\hline & $06 / 29$ & $07: 00 \mathrm{~h}$ & 10 & 10 & $1.9 \pm 0.3$ \\
\hline & $06 / 29$ & $20: 00 \mathrm{~h}$ & 10 & 7 & $0.8 \pm 0.3$ \\
\hline & 06/30 & $10: 00 \mathrm{~h}$ & 10 & 10 & $0.1 \pm 0.0^{\mathrm{a}}$ \\
\hline & 06/30 & $10: 00 \mathrm{~h}$ & 50 & 10 & $0.6 \pm 0.2$ \\
\hline & 07/02 & $10: 00 \mathrm{~h}$ & 22 & 9 & $0.7 \pm 0.5$ \\
\hline & 07/03 & $10: 00 \mathrm{~h}$ & 50 & 10 & $0.7 \pm 0.3$ \\
\hline & 07/03 & $10: 00 \mathrm{~h}$ & 75 & 10 & $1.3 \pm 0.5$ \\
\hline & 07/07 & $08: 00 \mathrm{~h}$ & 5 & 10 & $1.2 \pm 0.5$ \\
\hline \multirow[t]{3}{*}{4} & 07/08 & $10: 00 \mathrm{~h}$ & 5 & 19 & $0.2 \pm 0.2^{\mathrm{a}}$ \\
\hline & 07/08 & $10: 00 \mathrm{~h}$ & 50 & 19 & $0.7 \pm 0.3$ \\
\hline & 07/08 & $10: 00 \mathrm{~h}$ & 75 & 19 & $1.1 \pm 0.5$ \\
\hline \multirow[t]{6}{*}{5} & 07/09 & 08:00 h & 5 & 21 & $0.8 \pm 0.5$ \\
\hline & 07/09 & 08:00 h & 15 & 21 & $1.7 \pm 0.4$ \\
\hline & 07/09 & 08:00 h & 30 & 21 & $1.2 \pm 0.9$ \\
\hline & 07/09 & $08: 00 \mathrm{~h}$ & 40 & 21 & $1.0 \pm 0.3$ \\
\hline & 07/09 & $08: 00 \mathrm{~h}$ & 50 & 21 & $1.2 \pm 0.7$ \\
\hline & 07/09 & $08: 00 \mathrm{~h}$ & 75 & 21 & $0.0 \pm 0.2^{\mathrm{a}}$ \\
\hline
\end{tabular}

abundance was observed for the upper $75 \mathrm{~m}$ of the photic zone $\left(2.4 \pm 05 \times 10^{8}\right.$ cells l$\left.^{-1}, \mathrm{n}=23\right)$. Cyanobacteria and autotrophic nanoplankton averaged $0.22 \pm$ $0.19 \times 10^{7}$ cells l$^{-1}(\mathrm{n}=10)$ in the surface mixed layer and $0.32 \pm 0.22 \times 10^{7}$ cells l$^{-1}(\mathrm{n}=23)$ in the upper $75 \mathrm{~m}$ of the photic zone. Heterotrophic protists averaged $0.70 \pm 0.41 \times 10^{6}$ cells l$^{-1}(\mathrm{n}=10)$ in the surface mixed layer and $0.63 \pm 0.41 \times 10^{6}$ cells $^{-1}(\mathrm{n}=23)$ in the upper $75 \mathrm{~m}$ of the photic zone. No correlation between community respiration and abundance of any of the major metabolic groups of microorganisms was observed in the photic zone of the Sargasso Sea (Fig. 2).

\section{Size fractionation}

Respiration rates in the $<0.6 \mu \mathrm{m}$ size fraction of water collected in the surface mixed layer at BATS exhibited minimal variability among 3 experiments performed on separate days $\left(0.3\right.$ to $0.4 \mu^{-10} \mathrm{~d}_{2}{ }^{-1}$; Table 3). Respiration in the $<0.6 \mu \mathrm{m}$ size fraction accounted for $23 \pm 4 \%$ of community respiration. In contrast, heterotrophic bacterial abundance in the $<0.6 \mu \mathrm{m}$ size fraction accounted for $\sim 78 \%$ of the abundance in unfiltered seawater samples (Table 3). Addition of $\mathrm{P}$ to the $<0.6 \mu \mathrm{m}$ size fraction from the surface mixed layer (29 June) stimulated respiration by a factor of 1.8 , resulting in a respiration rate of $0.7 \pm 0.2 \mu \mathrm{MO}_{2} \mathrm{~d}^{-1}$ (Table 3).

\section{Long-term experiments}

Respiration in $0.6 \mu \mathrm{m}$ filtered seawater collected from $50 \mathrm{~m}$ at BATS was $1.3 \pm 0.3 \mu \mathrm{M} \mathrm{O}_{2}$ during the $10 \mathrm{~d}$

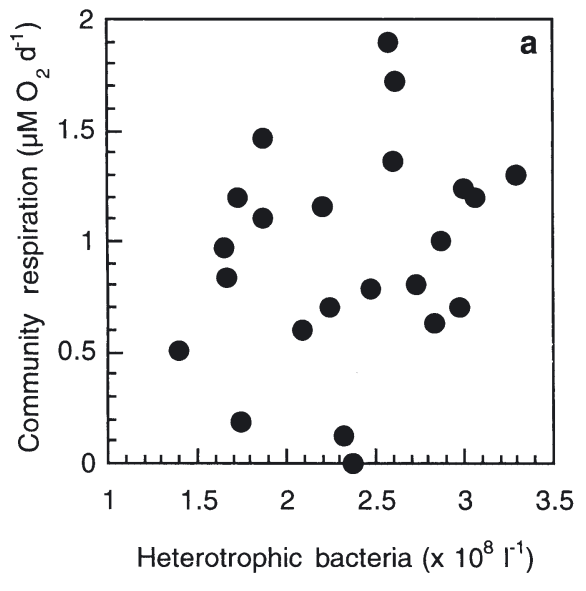

Heterotrophic bacteria $\left(\times 10^{8} \mathrm{I}^{-1}\right)$

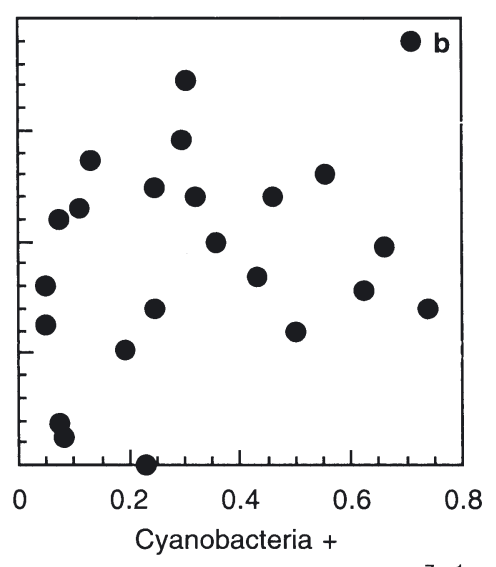

Phototrophic nanoplankton $\left(\times 10^{7} \mathrm{I}^{-1}\right)$

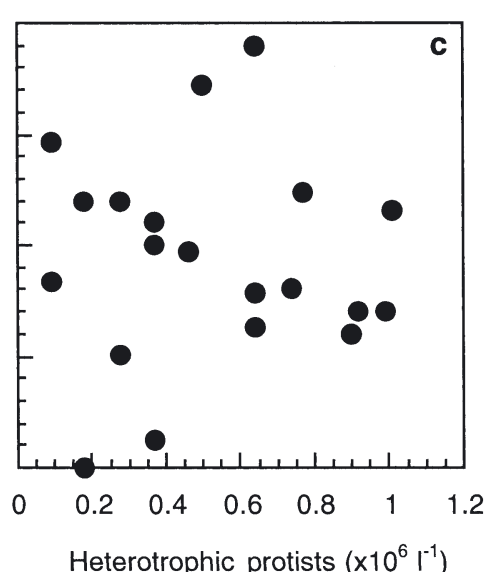

Heterotrophic protists $\left(\times 10^{6} I^{-1}\right)$

Fig. 2. Relationship between community respiration and the abundance of (a) heterotrophic bacteria, (b) cyanobacteria and phototrophic nanoplankton, and (c) heterotrophic protists 
Table 3. Respiration rates and bacterial abundance in unfiltered seawater and in the $<0.6 \mu \mathrm{m}$ size fraction collected in the surface mixed layer (SML) at the Bermuda Atlantic Timeseries Study (BATS) station. On one occasion (29 June) P was added to the $<0.6 \mu \mathrm{m}$ size fraction $\left(0.1 \mu \mathrm{M} \mathrm{PO}_{4}\right.$ final conc.). Respiration rates \pm pooled $\mathrm{SD}$ of initial and final dissolved oxygen concentration are shown; $\mathrm{n}=3$

\begin{tabular}{|c|c|c|c|c|}
\hline \multirow{2}{*}{$\begin{array}{l}\text { Date } \\
\text { (mm/dd }\end{array}$} & \multicolumn{2}{|c|}{$\begin{array}{l}\text { Respiration rate } \\
\left(\mu \mathrm{M} \mathrm{O}_{2} \mathrm{~d}^{-1}\right)\end{array}$} & \multicolumn{2}{|c|}{$\begin{array}{c}\text { Bacterial abundance } \\
\left(\times 10^{8} \text { cells } 1^{-1}\right)\end{array}$} \\
\hline & $\begin{array}{l}\text { Unfiltered } \\
\text { seawater }\end{array}$ & $\begin{array}{c}<0.6 \mu \mathrm{m} \text { size } \\
\text { fraction }\end{array}$ & $\begin{array}{l}\text { Unfiltered } \\
\text { seawater }\end{array}$ & $\begin{array}{c}<0.6 \mu \text { m size } \\
\text { fraction }\end{array}$ \\
\hline $06 / 27$ & $1.5 \pm 0.6$ & $0.3 \pm 0.2$ & 2.2 & 1.9 \\
\hline $06 / 28$ & $1.4 \pm 0.3$ & $0.4 \pm 0.2$ & 2.6 & 1.7 \\
\hline 06/29 & $1.9 \pm 0.3$ & $0.4 \pm 0.2$ & 2.6 & 2.1 \\
\hline $06 / 29$ & +P) & $0.7 \pm 0.2$ & 2.6 & 2.1 \\
\hline
\end{tabular}

incubation (Table 4). An increase in bacterial respiration was observed with depth during the $10 \mathrm{~d}$ incubation. At $300 \mathrm{~m}$, dissolved oxygen consumed during the $10 \mathrm{~d}$ incubation was 2-fold higher than at $50 \mathrm{~m}$. Bacterial abundance increased 2- and 4-fold in the $10 \mathrm{~d}$ incubations from 150 and $300 \mathrm{~m}$, respectively, while no net increase in bacterial abundance was observed in $0.6 \mu \mathrm{m}$ filtered seawater from $50 \mathrm{~m}$. In a separate experiment, the addition of $\mathrm{P}$ to the $<0.6 \mu \mathrm{m}$ size fraction from $50 \mathrm{~m}$ increased respiration 2.5 -fold during $5 \mathrm{~d}$ as compared to the unamended control (Table 4). Bacterial abundance increased by a factor of 1.3 in the unamended and P-amended $<0.6 \mu \mathrm{m}$ size fraction over the $5 \mathrm{~d}$ incubation period.
Table 4. Respiration and changes in bacterial abundance during long-term experiments with $0.6 \mu \mathrm{m}$ filtered seawater from different depths at the Bermuda Atlantic Time-series Study (BATS) station incubated at $20 \pm 1^{\circ} \mathrm{C}$. On 1 occasion $\mathrm{P}$ was added to the $<0.6 \mu \mathrm{m}$ size fraction $\left(0.1 \mu \mathrm{M} \mathrm{PO}_{4}\right.$ final conc.). Respiration \pm pooled SD of initial and final dissolved oxygen concentration are shown $; \mathrm{n}=4$

\begin{tabular}{|c|c|c|c|c|}
\hline \multirow[t]{2}{*}{$\begin{array}{l}\text { Depth } \\
\text { (m) }\end{array}$} & \multirow[t]{2}{*}{$\begin{array}{l}\text { Respiration } \\
\left(\text { in } \mu \mathrm{M} \mathrm{O}_{2} \text { ) }\right.\end{array}$} & \multicolumn{2}{|c|}{$\begin{array}{l}\text { Bacterial abundance } \\
\qquad\left(\times 10^{8} \text { cells } ~^{-1}\right)\end{array}$} & \multirow[t]{2}{*}{$\begin{array}{l}\text { Duration } \\
\text { (d) }\end{array}$} \\
\hline & & Initial & Final & \\
\hline 50 & $1.3 \pm 0.3$ & 2.1 & 2.1 & 10 \\
\hline 150 & $2.1 \pm 0.5$ & 1.0 & 1.9 & 10 \\
\hline 300 & $2.6 \pm 0.4$ & 0.7 & 2.5 & 10 \\
\hline 50 & $1.4 \pm 0.2$ & 2.0 & 2.6 & 5 \\
\hline $50(+P)$ & $3.5 \pm 0.3$ & 2.0 & 2.6 & 5 \\
\hline
\end{tabular}

\section{DISCUSSION}

Community respiration rates provide a direct measure of catabolic activity and are therefore excellent integrators of the cycling of organic carbon. Although the need for respiration measurements was emphasized previously (Williams 1981, Biddanda et al. 1994, Jahnke \& Craven 1995), measurements of respiration in ocean waters are scarce. This is particularly true for the oligotrophic regions of the open ocean that cover about $30 \%$ of the Earth's surface. The current debate whether the consumption of organic carbon exceeds its production in the oligotrophic ocean, and subsequently whether the open ocean can be considered net heterotrophic (del

\section{Nutrient enrichment experiments}

Addition of $\mathrm{P}$ to unfiltered seawater from the surface mixed layer at BATS and Stn 5 resulted in a significant increase (up to 2.8-fold) in respiration rates (paired $t$-test, $\mathrm{p}<0.05, \mathrm{n}=5$ ), while no stimulatory effect was observed upon addition of $\mathrm{N}$ or $\mathrm{C}$ (Fig. 3). However, stimulation of respiration rates by $\mathrm{P}$-addition was limited to the upper $30 \mathrm{~m}$ (Fig. 3). At 40, 50 and $75 \mathrm{~m}$ respiration rates were unaffected by the addition of P. Similarly, neither N nor C alone resulted in enhanced respiration rates at these depths. If unfiltered seawater was amended with a combination of $\mathrm{P}, \mathrm{N}$ and $\mathrm{C}$, respiration rates increased by a factor of 3 in the surface mixed layer, and by factors of 1.3 and 1.4 at 50 and $75 \mathrm{~m}$, respectively (Fig. 3).

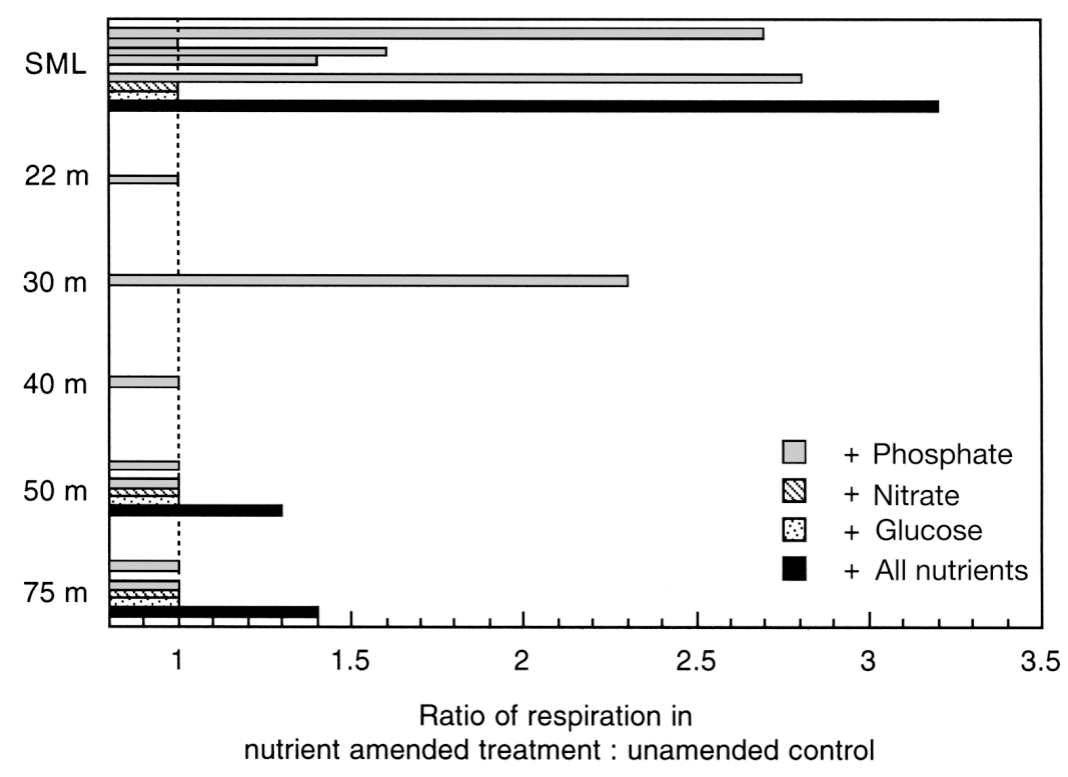

Fig. 3. Ratio of community respiration rates in nutrient-amended seawater to unamended controls at different depths at the Bermuda Atlantic Time-series Study (BATS) station and Stn 5. The surface mixed layer extended to 10 and $21 \mathrm{~m}$ at these stations, respectively. SML: surface mixed layer 
Giorgio et al. 1997, Duarte \& Agusti 1998, Williams 1998), further indicates the importance of understanding the mechanisms controlling these processes.

\section{Variability in community respiration}

An important observation of the present study is the considerable variability in community respiration rates in the photic zone of the Sargasso Sea. Spatial and temporal changes were also observed in the abundance of the major metabolic groups of the microbial community; however, none of these changes was significantly correlated with changes in community respiration rates. Even though the biomass of the major metabolic groups might provide a stronger relationship to respiration than abundance, we assume that the conversion of abundance to biomass would not result in a substantial change of the observed spatial and temporal variability within each of the major metabolic groups.

Measurements of biological activity in bottle incubations are often criticized for a variety of possible artifacts. A major concern is the uneven distribution of larger organisms or organic aggregates resulting in large variability among replicate incubation bottles. In the present study, the relative standard deviation of dissolved oxygen concentrations among replicates averaged $\sim 0.2 \%$, suggesting fairly uniform distributions of organisms and particles in the incubation bottles. In addition, incubations in 60 and $300 \mathrm{ml}$ bottles yielded similar results, and a linear decrease in the concentration of dissolved oxygen was observed over a $48 \mathrm{~h}$ incubation period. Thus, it appears that spatial and temporal variability in community respiration rates was not an artifact of bottle incubations, but resulted from in situ shifts in the metabolic activity of the plankton community. Shifts in bacterial metabolism have been shown to be attributable to highly variable percentages of active cells (Gasol et al. 1995, Zweifel \& Hagström 1995). Rapid stimulation of dormant or slow-growing cells was observed upon the addition of nutrients (Sherr et al. 1999), indicating a wide range in the metabolic activity of heterotrophic bacteria. In the present study, shifts in community respiration were very sensitive to changes in P-availability in the surface mixed layer, while colimitation of substrates prevailed at deeper layers of the photic zone. Furthermore, the response of community respiration to P-addition in the surface mixed layer revealed substantial variability among days. The observed spatial and temporal variability in community respiration therefore appears to be related to changes in nutrient and substrate supply and availability. We therefore suggest that the availability of $\mathrm{P}$, and possibly other substrates, is variable on short temporal and spa- tial scales, resulting in variable community respiration rates.

The average community respiration rate for surface waters of the Sargasso Sea determined in the present study $\left(1.1 \pm 0.4 \mu \mathrm{MO}_{2} \mathrm{~d}^{-1}\right)$ is somewhat lower than the average rate for the upper $25 \mathrm{~m}$ of the Sargasso Sea $\left(1.7 \pm 0.3 \mu \mathrm{MO}_{2} \mathrm{~d}^{-1}\right)$ reported by Williams \& Jenkinson (1982). Respiration rates reported for surface waters of the oligotrophic North Pacific Ocean averaged $0.84 \pm$ $0.5 \mathrm{MMO}_{2} \mathrm{~d}^{-1}$ (Williams \& Purdie 1991). The community respiration rates determined in the present study are within the range of values reported for surface waters of the oligotrophic ocean.

\section{Size-fractionation and bacterial respiration}

Estimating the bacterial contribution to overall metabolism has often been studied using size fractionation experiments (Azam \& Hodson 1977, Williams 1981, Hopkinson et al. 1989). Respiration measurements with size-fractionated water samples have mainly been performed with coastal seawater, revealing that respiration is dominated by the heterotrophic microbial fraction at low to moderate chlorophyll concentrations (Williams 1981, Kuparinen 1984, Iriarte et al. 1991, Chin-Leo \& Benner 1992). In a recent survey of lakes of varying trophic status, bacterial respiration ( $<1 \mu \mathrm{m}$ size fraction) accounted for $\sim 90 \%$ of plankton community respiration in the most oligotrophic systems (Biddanda et al. 2001). In the present study, bacterial respiration determined in size-fractionation $(<0.6 \mu \mathrm{m})$ experiments was on average $0.4 \mu \mathrm{MO}_{2} \mathrm{~d}^{-1}$ and contributed $23 \%$ to overall plankton community respiration at BATS. A similar respiration rate $\left(0.37 \mathrm{\mu MO}_{2} \mathrm{~d}^{-1}\right)$ was determined by Kepkay et al. (1990) in size-fractionated (2 $\mu \mathrm{m}$ filtered) water collected at $10 \mathrm{~m}$ in the Sargasso Sea. Hansell et al. (1995) measured carbon mineralization rates $(0.45 \mu \mathrm{M}$ $\left.\mathrm{C} \mathrm{d}^{-1}\right)$ in size-fractionated $(0.8 \mu \mathrm{m}$ pore size) water from $20 \mathrm{~m}$ at BATS.

The low bacterial contribution to plankton community respiration in the Sargasso Sea is surprising given that $\sim 80 \%$ of heterotrophic bacteria pass a $0.6 \mu \mathrm{m}$ pore-size filter. A similar observation was reported from the Gulf of Mexico, where respiration rates in the $<1 \mu \mathrm{m}$ size fraction were $\sim 10$-fold lower than rates in unfiltered seawater, although bacterial abundance was similar in both treatments (Biddanda et al. 1994). This pattern was only evident at the more oligotrophic site on the continental slope, whereas on the shelf bacterial respiration accounted for $\sim 50 \%$ of community respiration based on size-fractionation experiments (Biddanda et al. 1994). In the oligotrophic Mediterranean Sea, large seasonal variations in the contribu- 
tion of bacteria $(<0.8 \mu \mathrm{m}$ size fraction) to community respiration (16 to $>100 \%$ ) were observed in size fractionation experiments in the euphotic zone (Lemée et al. 2002). The relative contribution of the bacterial abundance in the $<0.8 \mu \mathrm{m}$ size fraction, however, did not vary substantially during the year, accounting for $\sim 80 \%$ of the bacterial abundance in unfiltered seawater. These results clearly indicate that size fractionation can substantially impact bacterial metabolic activity. Similarly, rates of bacterial carbon production can be dramatically reduced in size-fractionation experiments (Carlsson \& Caron 2001). These authors report a 70 to $90 \%$ decrease in bacterial production (measured as ${ }^{3} \mathrm{H}$-leucine incorporation) in $0.8 \mu \mathrm{m}$ filtered water as compared to unfiltered lake water, while size fractionation removed only $\sim 20 \%$ of the bacterial abundance.

Previous studies indicate a tight coupling among the various members of the microbial loop (e.g. Sherr et al. 1988), and we considered the potential consequences of the separation of these microorganisms in size-fractionation experiments with oligotrophic waters. Heterotrophic protists are known to efficiently regenerate inorganic nutrients which are essential for maintaining biological activity in oligotrophic environments (Andersson et al. 1985, Caron 1994). However, size fractionation separates heterotrophic protists from bacterioplankton, thereby uncoupling processes that regenerate inorganic nutrients. We therefore suggest that the absence of heterotrophic protists in size-fractionated samples, particularly from the P-limited surface mixed layer, is responsible for the low bacterial respiration rates in $0.6 \mu \mathrm{m}$ filtered seawater. Addition of $\mathrm{P}$ to $<0.6 \mu \mathrm{m}$ filtered water resulted in a $\sim 2$-fold increase in bacterial respiration rates in the present study.

Several other possibilities could, at least to some extent, contribute to the low bacterial respiration rates observed in the present study. Even though only 20\% of bacterial abundance was retained by $0.6 \mu \mathrm{m}$ filtration, this fraction of the bacterioplankton could account for more than $20 \%$ of bacterial respiration. Likewise, heterotrophic protists, cyanobacteria and phototrophic nanoflagellates could be responsible for a greater fraction of community respiration than previously recognized. In terms of biomass, these members of the microbial community have been reported to account for up to $60 \%$ of the overall microbial biomass in surface waters of the Sargasso Sea (Caron 1994). If community respiration in the surface mixed layer is predominantly attributable to these metabolic groups, a relationship between their abundance and community respiration would be expected. However, no such relationship was observed in the present study.

The determination of bacterial growth efficiency combines measurements of bacterial production and respiration to better understand the flow of carbon through heterotrophic bacterioplankton (del Giorgio \& Cole 2000). The experimental approaches commonly used in growth efficiency experiments, namely size fractionation and dilution, are designed to minimize the contribution of other microorganisms to metabolism. The present and previous studies (Biddanda et al. 1994, Carlsson \& Caron 2001, Lemée et al. 2002) raise the question of whether heterotrophic bacterial metabolism determined in size-fractionation and dilution experiments is representative of bacterial metabolism in unfiltered water. The complex structure of the microbial community and the interactions among the various members of the community are disrupted in these experiments. Our results indicate the potential for experimental artifacts when microbial groups are separated for measurements of activity in oligotrophic aquatic environments.

\section{P-limitation of community and bacterial respiration}

Nutrient enrichment experiments performed in the present and previous studies (Cotner et al. 1997, Rivkin \& Anderson 1997, Caron et al. 2000) support the idea that specific biological processes in surface waters of the Sargasso Sea are P-limited during the stratified summer period. In addition to bioassay experiments that suggest P-limitation, P-limitation is also indicated by high dissolved N:P (60:1) ratios (Wu et al. 2000) and short $\mathrm{P}$ turnover times $(5 \mathrm{~h})$ in planktonic biomass in surface waters of the Sargasso Sea (Cotner et al. 1997). Soluble reactive phosphorus (SRP) concentrations are below the limit of detection $(0.03 \mu \mathrm{M})$ throughout the upper $100 \mathrm{~m}$ water column during summer at BATS (data available at www.bbsr.edu/cintoo/bats/bats. $\mathrm{html}) . \mathrm{P}$ is a vital nutrient for all living organisms and is rapidly assimilated to form compounds that have critical structural (e.g. lipid membrane) and metabolic functions, such as protein synthesis, cell production and energy transport. Thus, $\mathrm{P}$ is an essential nutrient for energy production and biosynthesis, and P likely limits both growth and respiration. In the present study, $\mathrm{P}$ was the primary factor limiting community respiration in the surface mixed layer of the Sargasso Sea. Bacterial respiration was also P-limited during size fractionation experiments with Sargasso Sea surface water. These results suggest that phytoplankton production is also likely P-limited in the surface mixed layer. Carlson et al. (2002) observed that bacterial carbon production and DOC mineralization were co-limited by $\mathrm{P}, \mathrm{N}$ and $\mathrm{C}$ in dilution experiments with water from the surface mixed layer of the Sargasso Sea. Differences between these studies could result from temporal and spatial variability or differences between size fractionation and dilution culture experiments. 
Bacterial respiration was also P-limited in long-term experiments from $50 \mathrm{~m}$ at BATS. The overall respiration in $0.6 \mu \mathrm{m}$ filtered seawater incubated for 5 to $10 \mathrm{~d}$ was similar to respiration measured in unfiltered seawater during $24 \mathrm{~h}$ incubations $\left(\sim 1 \mu \mathrm{MO}_{2} \mathrm{~d}^{-1}\right)$. $\mathrm{P}$-addition to the long-term experiments from $50 \mathrm{~m}$ resulted in a 2.5 -fold increase in bacterial respiration. Based on results obtained from time-course and nutrient addition experiments we estimate that bacterial respiration in the unamended treatments probably decreases dramatically after $3 \mathrm{~d}$ due to P-limitation. The present study therefore confirms previous suggestions (Cotner et al. 1997, Rivkin \& Anderson 1997) that P-limitation could in part be responsible for the observed accumulation of DOC in the surface Sargasso Sea during summer (Carlson et al. 1994, Michaels 1994).

Bacterial respiration in the mesopelagic zone is likely limited by bioavailable $\mathrm{C}$, as the concentrations of nutrients increase and concentrations of DOC decrease rapidly below $\sim 125 \mathrm{~m}$. The relatively high bacterial respiration rates at 150 and $300 \mathrm{~m}$ indicate the potentially important contribution of mesopelagic metabolism to overall water-column metabolism, as has been pointed out by Biddanda \& Benner (1997).

\section{Implications for the oligotrophic ocean}

The oligotrophic ocean is often considered a stable and uniform environment. In contrast, these open ocean environments are characterized by a diverse and heterogenous plankton community (Giovannoni \& Rappe 2000, Sherr \& Sherr 2000). The present and previous studies further indicate that rates of metabolic activity of the plankton community exhibit substantial temporal and spatial variability in the euphotic zone of the oligotrophic ocean. This relatively fine-scale variability in biological processes likely reflects the spatial diversity of the open ocean (Azam 1998). Metabolic and spatial diversity appear to be important in open ocean environments and should be considered in future studies. Discovering the factors influencing finescale variability in biological processes will enhance the understanding of the dynamics of $\mathrm{C}$ cycling and the balance between the production and mineralization of $\mathrm{C}$ in the upper ocean.

Acknowledgements. We would like to thank D. Kirchman, Peter J. leB. Williams and 2 anonymous reviewers for helpful comments on an earlier draft of this manuscript, and the captain and the crew of RV 'Cape Hatteras' for their excellent technical assistance and great food. This work was supported by NSF grant OCE-0080782. I.O. acknowledges the receipt of a post-doctoral fellowship by the Austrian Science Foundation (Schrödinger-Grant J1989 - MOB).

\section{LITERATURE CITED}

Andersson A, Lee C, Azam F, Hagstrom A (1985) Release of amino acids and organic nutrients by heterotrophic marine flagellates. Mar Ecol Prog Ser 23:99-106

Azam F (1998) Microbial control of oceanic carbon flux: the plot thickens. Science 280:694-696

Azam F, Hodson RE (1977) Dissolved ATP in the sea and its utilization by marine bacteria. Nature 267:696-697

Biddanda B, Benner R (1997) Major contribution from mesopelagic plankton to heterotrophic metabolism in the upper ocean. Deep-Sea Res I 44:2069-2085

Biddanda B, Opsahl S, Benner R (1994) Plankton respiration and carbon flux through bacterioplankton on the Louisiana shelf. Limnol Oceanogr 39:1259-1275

Biddanda B, Ogdahl M, Cotner J (2001) Dominance of bacterial metabolism in oligotrophic relative to eutrophic waters. Limnol Oceanogr 46:730-739

Carlsson P, Caron DA (2001) Seasonal variation of phosphorus limitation of bacterial growth in a small lake. Limnol Oceanogr 46:108-120

Carlson CA, Ducklow HW, Michaels AF (1994) Annual flux of dissolved organic carbon from the euphotic zone in the northwestern Sargasso Sea. Nature 371:405-408

Carlson CA, Giovannoni SJ, Hansell DA, Goldberg SJ, Parsons R, Otero MP (2002) The effect of nutrient amendments on bacterioplankton production, community structure, and DOC utilization in the northwestern Sargasso Sea. Aquat Microb Ecol 30:19-36

Caron DA (1994) Inorganic nutrients, bacteria and the microbial loop. Microb Ecol 28:295-298

Caron DA, Lin EL, Sanders RW, Dennett MR, Berniger UG (2000) Response of bacterioplankton and phytoplankton to organic carbon and inorganic nutrient additions in contrasting oceanic systems. Aquat Microb Ecol 22: 175-184

Cherrier J, Bauer JE, Druffel ERM (1996) Utilization and turnover of labile dissolved organic matter by bacterial heterotrophs in eastern North Pacific surface waters. Mar Ecol Prog Ser 139:267-279

Chin-Leo G, Benner R (1992) Enhanced bacterioplankton production and respiration at intermediate salinities in the Mississippi River Plume. Mar Ecol Prog Ser 87:87-103

Cole JJ, Findlay S, Pace ML (1988) Bacterial production in fresh and saltwater ecosystems: a cross-system overview. Mar Ecol Prog Ser 43:1-10

Copin-Montégut G, Avril B (1993) Vertical distribution and temporal variation of dissolved organic carbon in the NorthWest Mediterranean Sea. Deep-Sea Res I 40:1963-1972

Cotner JB, Ammerman JW, Peele ER, Bentzen E (1997) Phosphorus-limited bacterioplankton growth in the Sargasso Sea. Aquat Microb Ecol 13:141-149

Currie DJ, Kalff J (1984) The relative importance of bacterioplankton and phytoplankton in phosphorus uptake in freshwater. Limnol Oceanogr 29:311-321

Danieri G, Riemann B, Williams PJleB (1994) In situ bacterial production and growth yield measured by thymidine, leucine and fractionated dark oxygen uptake. J Plankton Res 16:105-113

del Giorgio PA, Cole JJ (2000) Bacterial energetics and growth efficiency. In: Kirchman DL (ed) Microbial ecology of the oceans. Wiley-Liss, New York, p 289-325

del Giorgio PA, Cole JJ, Cimbleris A (1997) Respiration rates in bacteria exceed phytoplankton production in unproductive aquatic systems. Nature 385:148-151

Donachie SP, Christian JR, Karl DM (2001) Nutrient regulation of bacterial production and ectoenzyme activities in 
the subtropical North Pacific Ocean. Deep-Sea Res II 48: $1719-1732$

Duarte C, Agusti S (1998) The $\mathrm{CO}_{2}$ balance of unproductive aquatic ecosystems. Science 281:234-236

Ducklow H (2000) Bacterial production and biomass in the oceans. In: Kirchman DL (ed) Microbial ecology of the oceans. Wiley-Liss, New York, p 85-121

Gasol JM, del Giorgio PA, Massana R, Duarte CM (1995) ACtive versus inactive bacteria: size-dependence in a coastal marine plankton community. Mar Ecol Prog Ser 128:91-9

Giovannoni S, Rappe M (2000) Evolution, diversity, and molecular ecology of marine prokaryotes. In: Kirchman DL (ed) Microbial ecology of the oceans. Wiley-Liss, New York, p 47-84

Griffith PC, Douglas DJ, Wainright SC (1990) Metabolic activity of size-fractionated microbial plankton in estuarine, nearshore, and continental shelf waters of Georgia. Mar Ecol Prog Ser 59:263-270

Hansell DA, Bates NR, Gundersen K (1995) Mineralization of dissolved organic carbon in the Sargasso Sea. Mar Chem 51:201-212

Hopkinson CSJ, Sherr B, Wiebe WJ (1989) Size fractionated metabolism of coastal microbial plankton. Mar Ecol Prog Ser 51:155-166

Iriarte A, Daneri G, Garcia VMT, Purdie DA, Crawford DW (1991) Plankton community respiration and its relationship to chlorophyll a concentration in marine coastal waters. Oceanol Acta 14:379-388

Jahnke RA, Craven DB (1995) Quantifying the role of heterotrophic bacteria in the carbon cycle: a need for respiration rate measurements. Limnol Oceanogr 40:436-441

Kepkay PE, Harrison WG, Irwin B (1990) Surface coagulation, microbial respiration and primary production in the Sargasso Sea. Deep Sea Res I 37:145-155

Kirchman DL (1990) Limitation of bacterial growth by dissolved organic matter in the subarctic Pacific. Mar Ecol Prog Ser 62:47-54

Kirchman DL, Rich JR (1997) Regulation of bacterial growth rates by dissolved organic carbon and temperature in the Equatorial Pacific Ocean. Microb Ecol 33:11-20

Kirchman DL, Suzuki Y, Garside C, Ducklow HW (1991) High organic turnover rates of dissolved organic carbon during a spring phytoplankton bloom. Nature 352:612-614

Kuipers B, van Noort GJ, Vosjan J, Herndl GJ (2000) Diel periodicity of bacterioplankton in the euphotic zone of the subtropical Atlantic Ocean. Mar Ecol Prog Ser. 201:13-25

Kuparinen J (1984) Annual and seasonal fluctuation of primary productivity and overall respiration in a pelagic plankton community off Tvarminne, SW coast of Finland. Ophelia Suppl 3:111-122

Legendre L, Rassoulzadegan F (1995) Plankton and nutrient dynamics in marine waters. Ophelia 41:153-172

Lemée $R$, Rochelle-Newall E, Van Wambeke F, Pizay MD, Rinaldi P, Gattuso JP (2002) Seasonal variation of bacterial production, respiration and growth efficiency in the open NW Mediterranean Sea. Aquat Microb Ecol 29:227-237

Michaels AF (1994) Seasonal patterns of ocean biogeochemistry at the US JGOFS Bermuda Atlantic Time-Series Study site. Deep-Sea Res 41:1013-1038

Pomeroy LR, Sheldon JE, Sheldon WM Jr, Peters F (1995) Limits to growth and respiration of bacterioplankton in the Gulf of Mexico. Mar Ecol Prog Ser 117:259-268

Porter KG, Feig Y (1980) The use of DAPI for identifying and counting aquatic microflora. Limnol Oceanogr 25:943-946

Rivkin RB, Anderson MR (1997) Inorganic nutrient limitation of oceanic bacterioplankton. Limnol Oceanogr 42:730-740

Sampou P, Kemp WM (1994) Factors regulating plankton community respiration in Chesapeake Bay. Mar Ecol Prog Ser 110:249-258

Sherr EB, Sherr BF (2000) Marine microbes - an overview. In: Kirchman DL (ed) Microbial ecology of the oceans. WileyLiss, New York, p 13-46

Sherr BF, Sherr EB, Hopkinson CH (1988) Trophic interactions within pelagic microbial communities: indications of feedback regulation of carbon flow. Hydrobiologia 159:19-26

Sherr EB, Caron DA, Sherr BF (1993) Staining of heterotrophic protists for visualization via epifluorescence microscopy. In: Kemp PF, Sherr BF, Sherr EB, Cole JJ (eds) Handbook of methods for aquatic microbial ecology. Lewis Publishers, Boca Raton, FL, p 213-227

Sherr BF, del Giorgio PA, Sherr EB (1999) Estimating abundance and single-cell characteristics of respiring bacteria via the redox dye CTC. Aquat Microb Ecol 18:117-131

Smith EM, Kemp WM (2003) Planktonic and bacterial respiration along an estuarine gradient: responses to carbon and nutrient enrichment. Aquat Microb Ecol 30:251-261

Thingstad TF, Rassoulzadegan F (1995) Nutrient limitations, microbial food webs, and 'biological C-pumps': suggested interactions in a P-limited Mediterranean. Mar Ecol Prog Ser 117:299-306

Toolan T, Wehr JD, Findlay S (1991) Inorganic phosporus stimulation of bacterioplankton production in a mesoeutrophic lake. Appl Environ Microbiol 57:2074-2078

Vadstein O, Jensen A, Olsen Y, Reinertsen H (1988) Growth and phosphorus status of limnetic phytoplankton and bacteria. Limnol Oceanogr 33:489-503

White PA, Kalff J, Rasmussen JB, Gasol JM (1991) The effect of temperature and algal biomass on bacterial production and specific growth rate in freshwater and marine habitats. Microb Ecol 21:99-118

Williams PJleB (1981) Microbial contribution to overall marine plankton metabolism: direct measurements of respiration. Oceanol Acta 4:359-364

Williams PJleB (1984) A review of measurements of respiration rates of marine plankton populations In: Hobbie JE, Williams PJleB (eds) Heterotrophic activity in the sea. Plenum Press, New York, p 357-289

Williams PJleB (1995) Evidence for the seasonal accumulation of carbon-rich dissolved organic material, its scale in comparison with changes in particulate material and the consequential effect on net $\mathrm{C} / \mathrm{N}$ assimilation ratios. Mar Chem 51:17-29

Williams PJleB (1998) The balance of plankton respiration and photosynthesis in the open oceans. Nature 394:55-57

Williams PJleB, Jenkinson NW (1982) A transportable microprocessor-controlled precise Winkler titration suitable for field station and shipboard use. Limnol Oceanogr 27: 576-584

Williams PJleB, Purdie DA (1991) In vitro and in situ derived rates of gross production, net community production and respiration of oxygen in the oligotrophic subtropical gyre of the North Pacific Ocean. Deep-Sea Res 38:891-910

Wu J, Sunda W, Boyle EA, Karl DM (2000) Phosphate depletion in the western north Atlantic Ocean. Science 289: $759-762$

Zweifel UL, Hagström A (1995) Total counts of marine bacteria include a large fraction of non-nucleoid-containing bacteria (ghosts). Appl Environ Microbiol 61:2180-2185

Zweifel UL, Norrman B, Hagström A (1993) Consumption of dissolved organic carbon by marine bacteria and demand for inorganic nutrients. Mar Ecol Prog Ser 101:23-32

Zweifel UL, Wikner J, Hagström A, Lundberg E, Norrman B (1995) Dynamics of dissolved organic carbon in a coastal ecosystem. Limnol Oceanogr 40:299-305 